\title{
INTEGRASI SERVQUAL, KANO DAN QFD UNTUK ANALISIS PENINGKATAN KUALITAS LAYANAN DEMI TERCAPAINYA KEPUASAN PELANGGAN PT. KHARISMA SEJAHTERA DAIHATSU CABANG BOJONEGORO
}

\author{
Rizky Stighfarrinata \\ Universitas Bojonegoro \\ stighfarrinatarizky@gmail.com \\ Faisal Ashari \\ Universitas Bojonegoro \\ faisal.gaxes@gmail.com
}

\begin{abstract}
PT. Kharisma Sejahtera adalah salah satu perusahaan yang menjual mobil hasil produksi Daihatsu dan dikenal sebagai dealer favorit dan terpercaya, khususnya di daerah Bojonegoro yang melayani calon pembelidan dan service. Tujuan penelitian ini adalah menganalisis dan meningkatkan kualitas layanan untuk memuaskan calon pembeli dengan integrasi metode Servqual, Kano, dan Quality Function Deployment. Hasil penelitian Servqual menunjukkan bahwa kualitas layanan yang diberikan belum mampu memenuhi harapan mahasiswa, karena semua atribut memiliki nilai Gap negatif. Untuk hasil penelitian Kano diperoleh 4 atribut Must-be, 14 atribut One-dimensional, 1 atribut Attractive, dan 1 atribut Indifferent. Sedangkan dari hasil penelitian Quality Function Deployment diperoleh 12 Technical Requirements yang perlu diprioritaskan dalam meningkatan kualitas layanan, dengan 5 kontribusi tertinggi Technical Requirements adalah membuat SOP dalam menanggapi keluhan calon pembeli dan pelanggan $18.77 \%$, memberikan pelatihan dan training secara berkala pada semua karyawan dan staff $17.06 \%$, melakukan evaluasi kinerja karyawan dan staff secara rutin $15.46 \%$, membuat sistem informasi untuk membantu memberikan informasi secara umum $10.58 \%$, dan melakuan check up produk secara berkala $10.43 \%$.
\end{abstract}

Keywords: Kano; Quality Function Diagram; Servqual; Satisfaction; Service Quality

\section{PENDAHULUAN}

Pada zaman modern saat ini, kebutuhan masyarakat akan suatu alat transportasi sangat tinggi dan semakin meningkat. Hal ini, mengakibatkan banyaknya perusahaan yang bergerak dalam produksi transportasi khususnya mobil menjadi sangat populer. Hal ini menjadi salah satu faktor terciptanya persaingan antar perusahaan yang memproduksi mobil di suatu negara, tidak terkecuali Indonesia. Hal ini memicu tingkat persaingan antar produsen mobil semakin cepat. Akan tetapi, dengan banyaknya produsen mobil, konsumen harus jeli dalam memilih produsen. Sehingga, bisa menimbulkan rasa kepuasan terhadap konsumen Ketika 
menggunakan jasa atau membeli produk dari produsen mobil yang dipilih. Untuk mengetahui tingkat kepuasan pelanggan maka penelitian ini dilakukan, penelitian ini dilakukan dengan mereferensikan pada beberapa penelitian yang sudah ada sebelumnya yang sudah dilaksanakan pada penelitian (Aji et al., 2021) dan juga mengambil beberapa referensi pada penelitian yang telah dilakukan oleh (Utami, 2015), (Sutariah, 2017), (Wibisono, 2018), (Yusuf R et al., 2017), dan (Nurfadli et al., 2020).

\section{KAJIAN PUSTAKA DAN PENGEMBANGAN HIPOTESIS}

\section{Bauran Pemasaran}

Menurut Kotler \& Armstrong (2012) bauran pemasaran merupakan serangkaian alat pemasaran yang digunakan untuk mencapai suatu tujuan organisasi dan diintegrasikan oleh perusahaan untuk mendapatkan tanggapan dari pasar sasaran yang diinginkan. Seperti yang dijelaskan dalam Farida dkk (2016), metode bauran pemasaran menitik beratkan pada berbagai macam faktor yang kemudian dikenal dengan 4P yang merupakan produk (product), harga (price), tempat (place), dan promosi (promotion). Seiring dengan berkembangnya zaman, faktor-faktor tersebut meluas menjadi 7P yaitu, produk (product), harga (price), tempat (place), promosi (promotion), orang (people), proses (process), dan bukti langsung (physical evidence).

\section{Jasa}

Menurut Kotler \& Armstrong (2012) dalam Ahimsa dkk (2013) menyatakan bahwa jasa merupakan suatu kegiatan atau tindakan yang diberikan kepada pelanggan, yang pada dasarnya tidak berwujud dan tidak mengakibatkan kepemilikan apapun. Adapun karakteristik jasa menurut Japarianto dkk (2007) antara lain tidak berwujud (intangibility), ketidakterpisahkan (inseparability), keragaman (variability), dan tidak tahan lama (perishability).

\section{Kualitas Pelayanan}

Dalam Puspitasari \& Lukmandono (2019) menyatakan bahwa setiap lembaga atau perusahaan penyedia jasa diharuskan untuk menanamkan kepercayaan sejak awal terhadap pelanggan akan kualitas jasa yang diberikannya. Hal ini, dilakukan untuk memenuhi persepsi dari pelanggan terhadap pelayanan yang diterima atau dirasakan. Jika ekspektasi yagn diharapkan dan kenyataan yang diterima sama, maka bisa dikatakan bahwa pelayanan sebuah perusahaan terebut memuaskan. 


\section{Servqual}

Metode Servqual mengkombinasikan dua kalimat yaitu "Layanan" dan "Kualitas". Alat ini dipopulerkan dan dikembangkan oleh Parasuraman, Zeithaml, dan Berry, (1985). Dalam penelitian yang dilakukan oleh Alam \& Mondal (2019), metode Servqual memiliki lima dimensi untuk mengukur kualitas sebuah layanan antara lain berwujud (tangible), keandalan (reliability), ketanggapan atau kepedulian (responsiveness), jaminan (assusrance), dan perhatian (empati). Untuk mengukur nilai Servqual dengan menggunakan kuesioner (Beheshtinia \& Azad, 2017) menggunakan rumus :

$\mathrm{Q}=\mathrm{P}-\mathrm{E}$

Dimana:

$$
\begin{aligned}
& \mathrm{Q}=\text { Nilai kesenjangan }(\text { The Quality od Service) } \\
& \mathrm{P}=\text { Persepsi Pelanggan }(\text { Customer Perception }) \\
& \text { E }=\text { Harapan Pelanggan }(\text { Customer Expected })
\end{aligned}
$$

\section{Kano}

Kano mengklasifikasikan preferensi pelanggan menjadi beberapa kategori untuk membantu mendapatkan pemahaman mengenai kepuasan pelanggan, yaitu (Lo dkk, 2016). Jika digambarkan, Kano memiliki bentuk sebagai berikut:

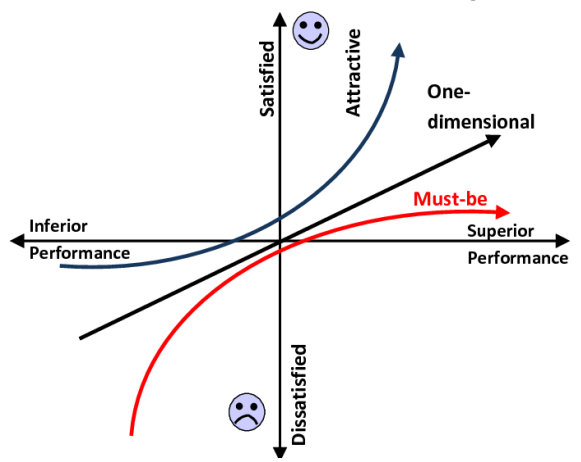

\section{Gambar 1. MODEL KANO}

Kategori Kano dibagi menjadi 6 dimensi antara lain Must-be yang merupakan kategori dasar dan harus ada pada sebuah produk atau jasa, One-dimensional yang berhubungan kepuasan pelanggan sealan dengan kinerja atau kualitas atribut yang diberikan, Attractive menentukan meningkat atau tidaknya kepuasan pelanggan, Indifferent tidak mempengaruhi kinerja dari sebuah atribut yang sudah ditentukan, Reverse berhubungan dengan terpenuhi atau tidaknya persyaratan atau atribuy dari suatu layanan, Questionable merupakan atribut atau kategori yang tidak valid atau dipertanyakan terpenuhi atau tidaknya atirbut tersebut. 


\section{Proses Evaluasi Model Kano}

Untuk menghitung Kano, menggunakan tabel Kano dibawah ini:

Tabel 1.

EVALUASI MODEL KANO

\begin{tabular}{|c|c|c|c|c|c|c|}
\hline \multirow{2}{*}{\multicolumn{2}{|c|}{$\begin{array}{c}\text { Customer } \rightarrow \\
\text { Requirement } \\
\downarrow\end{array}$}} & \multicolumn{5}{|c|}{ Dysfunctional } \\
\hline & & 1 & 2 & 3 & 4 & 5 \\
\hline \multirow{5}{*}{ 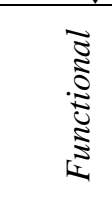 } & 1 & $\mathrm{Q}$ & A & A & A & $\mathrm{AlO}$ \\
\hline & 2 & $\mathrm{R}$ & I & I & I & $\mathrm{M}$ \\
\hline & 3 & $\mathrm{R}$ & I & I & I & $\mathrm{M}$ \\
\hline & 4 & $\mathrm{R}$ & I & I & I & $\mathrm{M}$ \\
\hline & 5 & $\mathrm{R}$ & $\mathrm{R}$ & $\mathrm{R}$ & $\mathrm{R}$ & $\mathrm{Q}$ \\
\hline
\end{tabular}

Sumber: (Rahmana dkk, 2014)

Keterangan:

$\begin{array}{ll}\mathrm{Q}=\text { Questionable } & \text { 1. Suka } \\ \mathrm{R}=\text { Reverse } & \text { 2. Mengharapkan } \\ \mathrm{A}=\text { Attractive } & \text { 3. Netral } \\ \mathrm{I}=\text { Indifferent } & \text { 4. Memberikan Toleransi } \\ \mathrm{O}=\text { One dimensional } & \text { 5. Tidak Suka } \\ \mathrm{M}=\text { Must be } & \end{array}$

\section{Quality Function Deployment}

HOQ atau rumah kualitas merupakan matrikss yang terdiri atas enam bagian, bagian-bagian tersebut sebagai berikut (Deveci dkk, 2019), gambarnya sebagai berikut:

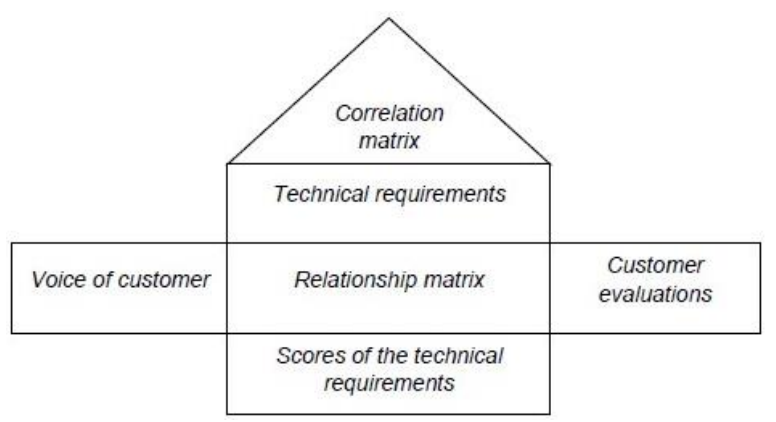

\section{Gambar 2. HOUSE OF QUALITY}

Menurut Deveci dkk (2019) House of Quality terdiri atas 6 bagian, antara lain voice of customer, technical requirements, customer evaluations (planning matrix), relationship matrix, correlation matrix, dan score of the technical requirements. Dalam penelitian ini yang akan digunakan, antara lain: 
Tingkat kepuasan pelanggan $($ customer satisfaction $)=\frac{\sum \text { Skala tingkat kepuasan }}{\sum \text { Jumlah responden }}$

Improvement ratio $=\frac{\text { Goal }}{\text { Customer satisfaction performance }}$

Sales Point yang mana nilainya dibagi menjadi 3 yaitu rendah nilainya 1, sedang nilainya 1.2 , dan tinggi nilainya 1.5 .

Raw Weight $=$ Absolure adjust importance $x$ Improvement ratio $x$ Sales point

Normalized raw weight $=\frac{\text { Raw weight }}{\text { Raw weight toal }} \times 100 \%$

Relationship Matrix = menggukan simbol $\Delta$ bernilai 1, O bernilai 3, bernilai 9.. (6) Correlation Matrix dibedakan berdasarkan dengan simbol nya, ++ artinya korealasi positif kuat, + artinya korelasi positif, -- artinya korelasi negatif kuat, - artinya korelasi negatif lemah

\section{Integrasi Metode Servqual, Kano dan QFD}

Kerangka kerja kombinasi antara metode Servqual dan Kano dapat dilihat pada gambar 2.4 (Tan \& Pawitra,2001).

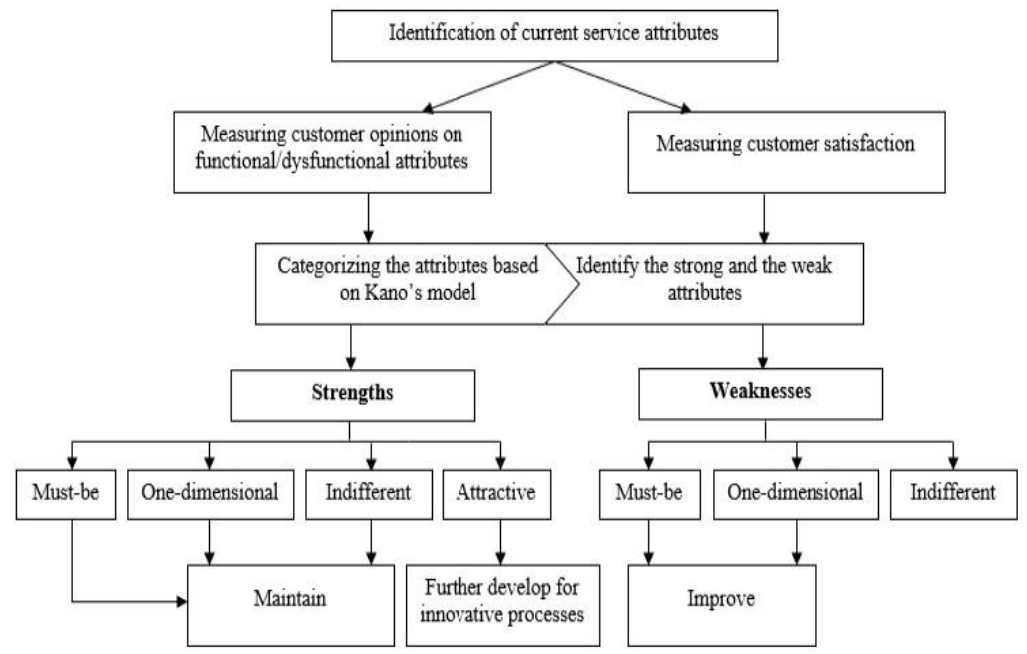

\section{Gambar 3. KERANGKA KERJA KOMBINASI SERVQUAL DAN KANO}

Di dalam melakukan integrasi metode Servqual, Kano, dan QFD dapat dilakukan dengan langkah sesuai berikut: 

demi tercapainya kepuasan pelanggan PT. Kharisma Sejahtera Daihatsu Cabang Bojonegoro

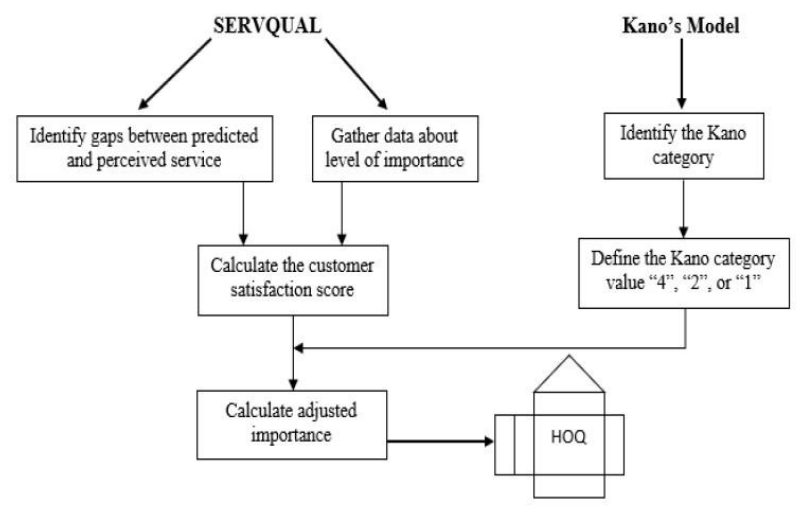

\section{Gambar 4. KERANGKA KERJA INTEGRASI SERVQUAL, KANO, DAN QFD}

\section{METODE PENELITIAN}

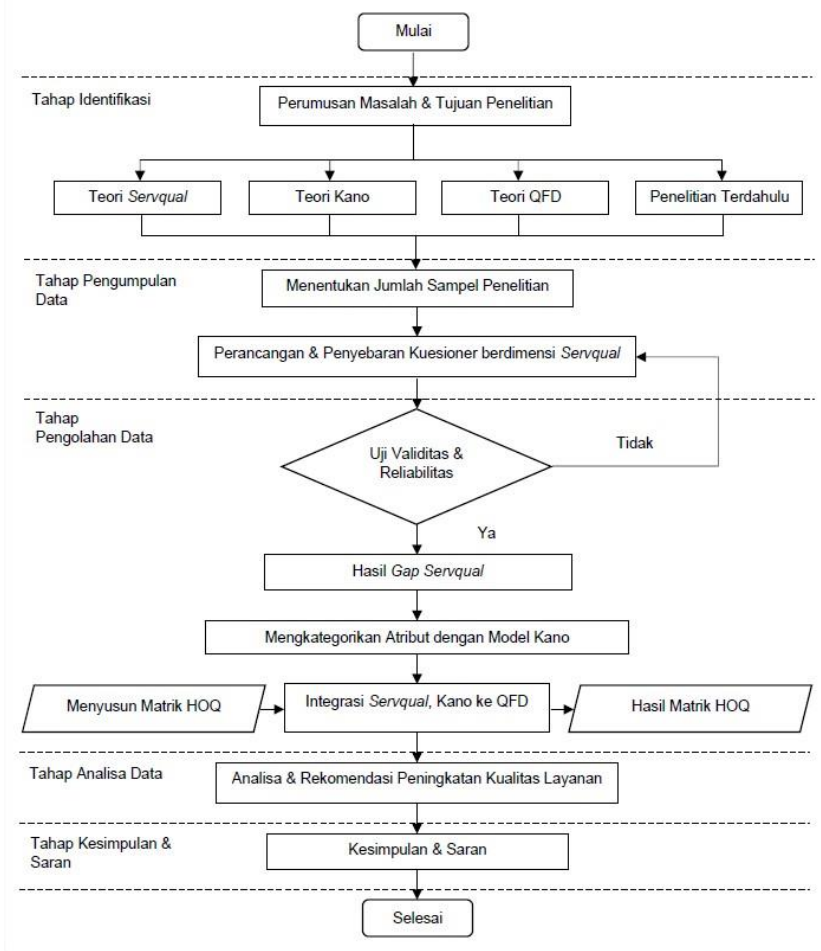

Gambar 5. FLOWCHART PENELITIAN 


\section{HASIL DAN PEMBAHASAN}

\section{Perancangan dan Penyebaran Kuesioner}

Setelah melakukan observasi dan wawancara kepada calon pembeli dan pelanggan PT. Kharisma Sejahtera Daihatsu yang merupakan calon responden dalam penelitian ini, serta konsultasi dengan pihak PT. Kharisma Sejahtera Daihatsu dan diperkaya dengan sumber pustaka yang berkaitan dengan penelitian ini. Maka didapatkan 20 atribut layanan di PT. Kharisma Sejahtera Daihatsu yang berdasarkan pada lima dimensi servqual, yang terdiri atas 4 atribut tangible, 4 atribut reliability, 4 atribut responsiveness, 4 atribut assurance, dan 4 atribut emphaty. Atribut tersebut dituliskan dalam tabel dibawah ini:

Tabel 2.

\section{ATRIBUT KUESIONER}

\begin{tabular}{|c|c|c|}
\hline Dimensi & No. & Atribut Layanan \\
\hline \multirow{4}{*}{$\begin{array}{c}\text { Tangible } \\
\text { (Berwujud) }\end{array}$} & 1 & Tempat ibadah yang bersih, rapi, dan nyaman \\
\hline & 2 & $\begin{array}{l}\text { Kelayakan fasilitas ruang tunggu (Televisi, AC, Kipas angin, } \\
\text { tempat duduk dll) }\end{array}$ \\
\hline & 3 & Kelayakan toilet \\
\hline & 4 & Kelayakan area parkir \\
\hline \multirow{4}{*}{$\begin{array}{l}\text { Reliability } \\
\text { (Keandalan) }\end{array}$} & 5 & Proses servis dijalankan dengan baik dan lancar \\
\hline & 6 & Servis bisa selesai tepat waktu \\
\hline & 7 & $\begin{array}{l}\text { Kesesuaian spesifikasi produk dengan ekspektasi calon } \\
\text { pembeli dan pelanggan }\end{array}$ \\
\hline & 8 & Kesesuaian jam buka tutup operasi \\
\hline \multirow{4}{*}{$\begin{array}{l}\text { Responsiveness } \\
\text { (Daya Tanggap) }\end{array}$} & 9 & $\begin{array}{l}\text { Ketanggapan pihak perusahaan merespon dan menaggapi } \\
\text { keluhan calon pembeli dan pelanggan. }\end{array}$ \\
\hline & 10 & $\begin{array}{l}\text { Kecepatan petugas administrasi dalam menyampaikan } \\
\text { informasi terbaru kepada petugas servis dan staff yang } \\
\text { bertanggung jawab }\end{array}$ \\
\hline & 11 & $\begin{array}{l}\text { Petugas resepsionis dan sales melayani calon pembeli dan } \\
\text { pelanggan dengan baik }\end{array}$ \\
\hline & 12 & Pimpinan dan staff standby selama jam kerja \\
\hline \multirow{4}{*}{$\begin{array}{l}\text { Assurance } \\
\text { (Jaminan) }\end{array}$} & 13 & $\begin{array}{l}\text { Suasana servis dan penjualan yang kondusif } \\
\text { menyenangkan }\end{array}$ \\
\hline & 14 & $\begin{array}{l}\text { Staff dan karyawan melayani calon pembeli dan pelanggan } \\
\text { dengan ramah dan sopan }\end{array}$ \\
\hline & 15 & Lingkungan perusahaan yang aman dan nyaman \\
\hline & 16 & Konsultasi dalam rencana pembelian dan servis kendaraan \\
\hline
\end{tabular}


Rizky Stighfarrinata, Faisal Ashari

Integrasi Servqual, Kano dan QFD untuk Analisis peningkatan kualitas layanan

demi tercapainya kepuasan pelanggan PT. Kharisma Sejahtera Daihatsu

Cabang Bojonegoro

Jurnal MANOVA Volume V Nomor 1, ISSN : 2685-4716, E ISSN : 2746-282X

Tabel 2.

ATRIBUT KUESIONER (LANJUTAN)

\begin{tabular}{ccl}
\hline Dimensi & No. & \multicolumn{1}{c}{ Atribut Layanan } \\
\hline & 17 & $\begin{array}{l}\text { Kemudahan staff untuk dihubungi guna mendapat pelayanan } \\
\text { sesuai masalah yang dihadapi }\end{array}$ \\
$\begin{array}{c}\text { Emphaty } \\
\text { (Perhatian) }\end{array}$ & 18 & $\begin{array}{l}\text { Tersedianya diskon atau promo menarik } \\
\text { Resepsionis memberi arahan sesuai dengan kebutuhan calon } \\
\text { pembeli dan pelanggan }\end{array}$ \\
& 20 & $\begin{array}{l}\text { Pelayanan terhadap calon pembeli dan pelanggan tidak dilihat } \\
\text { dari status sosial (adil) }\end{array}$ \\
\hline
\end{tabular}

Uji Validitas dan Reliabilitas

Tabel 7.

Hasil Uji Validitas

\begin{tabular}{|c|c|c|c|c|c|c|c|}
\hline \multirow{2}{*}{ Kuesioner } & \multirow{2}{*}{$\begin{array}{c}\mathrm{R} \\
\text { Tabel } \\
\end{array}$} & \multicolumn{5}{|c|}{ R Hitung } & \multirow{2}{*}{ Hasil } \\
\hline & & Persepsi & Harapan & Kepentingan & Fungsional & Disfungsional & \\
\hline Atribut 1 & 0.168 & $0.564 * *$ & $0.618 * *$ & $0.744 * *$ & $0.418 * *$ & $0.384 * *$ & Valid \\
\hline Atribut 2 & 0.168 & $0.537 * *$ & $0.508 * *$ & $0.741 * *$ & $0.447 * *$ & $0.622 * *$ & Valid \\
\hline Atribut 3 & 0.168 & $0.460 * *$ & $0.651 * *$ & $0.769 * *$ & $0.412 * *$ & $0.609 * *$ & Valid \\
\hline Atribut 4 & 0.168 & $0.355^{* *}$ & $0.637 * *$ & $0.672 * *$ & $0.401 * *$ & $0.409 * *$ & Valid \\
\hline Atribut 5 & 0.168 & $0.430 * *$ & $0.719 * *$ & $0.802 * *$ & $0.522 * *$ & $0.707 * *$ & Valid \\
\hline Atribut 6 & 0.168 & $0.371 * *$ & $0.713 * *$ & $0.801 * *$ & $0.444 * *$ & $0.343 * *$ & Valid \\
\hline Atribut 7 & 0.168 & $0.634 * *$ & $0.761 * *$ & $0.783 * *$ & $0.548 * *$ & $0.529 * *$ & Valid \\
\hline Atribut 8 & 0.168 & $0.488 * *$ & $0.607 * *$ & $0.789 * *$ & $0.422 * *$ & $0.543 * *$ & Valid \\
\hline Atribut 9 & 0.168 & $0.667 * *$ & $0.789 * *$ & $0.776 * *$ & $0.511 * *$ & $0.306 * *$ & Valid \\
\hline Atribut 10 & 0.168 & $0.399 * *$ & $0.569 * *$ & $0.754 * *$ & $0.321 * *$ & $0.466 * *$ & Valid \\
\hline Atribut 11 & 0.168 & $0.534 * *$ & $0.769 * *$ & $0.836 * *$ & $0.433 * *$ & $0.431 * *$ & Valid \\
\hline Atribut 12 & 0.168 & $0.571 * *$ & $0.767 * *$ & $0.813 * *$ & $0.491 * *$ & $0.468 * *$ & Valid \\
\hline Atribut 13 & 0.168 & $0.584 * *$ & $0.715 * *$ & $0.821 * *$ & $0.348 * *$ & $0.531 * *$ & Valid \\
\hline Atribut 14 & 0.168 & $0.509 * *$ & $0.660 * *$ & $0.784 * *$ & $0.464 * *$ & $0.552 * *$ & Valid \\
\hline Atribut 15 & 0.168 & $0.749 * *$ & $0.782 * *$ & $0.758 * *$ & $0.435 * *$ & $0.585 * *$ & Valid \\
\hline Atribut 16 & 0.168 & $0.622 * *$ & $0.695 * *$ & $0.722 * *$ & $0.463 * *$ & $0.502 * *$ & Valid \\
\hline Atribut 17 & 0.168 & $0.718^{* *}$ & $0.817 * *$ & $0.857 * *$ & $0.520 * *$ & $0.611 * *$ & Valid \\
\hline Atribut 18 & 0.168 & $0.552 * *$ & $0.746 * *$ & $0.778 * *$ & $0.509 * *$ & $0.547 * *$ & Valid \\
\hline Atribut 19 & 0.168 & $0.528 * *$ & $0.693 * *$ & $0.780 * *$ & $0.577 * *$ & $0.507 * *$ & Valid \\
\hline Atribut 20 & 0.168 & $0.613 * *$ & $0.780 * *$ & $0.746 * *$ & $0.352 * *$ & $0.529 * *$ & Valid \\
\hline
\end{tabular}

Berdasarkan hasil perhitungan uji validitas diatas, bisa disimpulkan bahwa 20 atribut yang ada dalam kuesioner pertanyaan persepsi, harapan, kepentingan, fungsional, dan disfungsional, diperoleh 20 attribut valid dikarenakan nilai tingkat signifikansi diatas 0,1 atau nilai $r$ hitung lebih dari 0.168. 


\section{Tabel 8.}

\section{Hasil Uji Reliabilitas}

\begin{tabular}{lccc}
\hline \multicolumn{1}{c}{ Kuesioner } & R Tabel & Cronbach's Alpha & Hasil \\
\hline Persepsi & 0.168 & 0.871 & Reliable \\
Harapan & 0.168 & 0.946 & Reliable \\
Kepentingan & 0.168 & 0.965 & Reliable \\
Fungsional & 0.168 & 0.777 & Reliable \\
Disfungsional & 0.168 & 0.846 & Reliable \\
\hline
\end{tabular}

Berdasarkan hasil perhitungan uji reliabilitas pada tabel 8, dapat disimpulkan bahwa atribut-atribut pada pertanyaan persepsi, harapan, kepentingan, fungsional, dan disfungsional dinyatakan reliable dan dapat digunakan sebagai input dari analisis data dikarenakan nilai Cronbach's Alpha $>$ dari nilai r tabel $(0,168)$.

Nilai Persepsi, Harapan, dan Kepentingan

Tabel 9.

Nilai Persepsi, Harapan, Kepentingan

\begin{tabular}{|c|c|c|c|c|}
\hline No & $\begin{array}{l}\text { Atribut Layanan } \\
\end{array}$ & Persepsi & Harapan & Kepentingan \\
\hline 1 & Tempat ibadah yang bersih, rapi, dan nyaman & 3.87 & 4.18 & 4.38 \\
\hline 2 & $\begin{array}{l}\text { Kelayakan fasilitas ruang tunggu (Televisi, } \\
\text { AC, Kipas angin, tempat duduk dll) }\end{array}$ & 3.62 & 4.03 & 4.52 \\
\hline 3 & Kelayakan toilet & 3.68 & 3.97 & 4.41 \\
\hline 4 & Kelayakan area parkir & 3.00 & 3.93 & 4.14 \\
\hline 5 & $\begin{array}{l}\text { Proses servis dijalankan dengan baik dan } \\
\text { lancar }\end{array}$ & 3.12 & 3.92 & 4.41 \\
\hline 6 & Servis bisa selesai tepat waktu & 3.62 & 4.13 & 4.20 \\
\hline 7 & $\begin{array}{l}\text { Kesesuain spesifikasi produk dengan } \\
\text { ekspektasi calon pembeli dan pelanggan }\end{array}$ & 3.88 & 4.36 & 4.47 \\
\hline 8 & Kesesuaian jam buka tutup operasi & 3.08 & 4.00 & 4.45 \\
\hline 9 & $\begin{array}{l}\text { Ketanggapan pihak perusahaan merespon } \\
\text { dan menanggapi keluhan calon pembeli dan } \\
\text { pelanggan }\end{array}$ & 3.72 & 4.26 & 4.47 \\
\hline 10 & $\begin{array}{l}\text { Kecepatan petugas administrasi dalam } \\
\text { menyampaikan informasi terbaru kepada } \\
\text { petugas servis dan staff yang bertanggung } \\
\text { jawab }\end{array}$ & 3.36 & 3.95 & 4.11 \\
\hline 11 & $\begin{array}{l}\text { Petugas resepsionis dan sales melayani calon } \\
\text { pembeli dan pelanggan dengan baik }\end{array}$ & 3.52 & 4.04 & 4.49 \\
\hline 12 & Pimpinan dan staff standby selama jam kerja & 3.94 & 4.23 & 4.45 \\
\hline 13 & $\begin{array}{l}\text { Suasana servis dan penjualan yang kondusif } \\
\text { dan menyenangkan }\end{array}$ & 3.45 & 4.15 & 4.13 \\
\hline 14 & $\begin{array}{l}\text { Staff dan karyawan melayani calon pembeli } \\
\text { dan pelanggan dengan ramah dan sopan }\end{array}$ & 3.28 & 3.96 & 4.13 \\
\hline
\end{tabular}




\section{Tabel 9.}

Nilai Persepsi, Harapan, Kepentingan (lanjutan)

\begin{tabular}{|c|c|c|c|c|}
\hline No & Atribut Layanan & Persepsi & Harapan & Kepentingan \\
\hline 15 & $\begin{array}{l}\text { Lingkungan perusahaan yang aman dan } \\
\text { nyaman }\end{array}$ & 3.78 & 4.16 & 4.28 \\
\hline 16 & $\begin{array}{l}\text { Konsultasi dalam rencana pembelian dan } \\
\text { servis kendaraan }\end{array}$ & 3.83 & 4.22 & 4.42 \\
\hline 17 & $\begin{array}{l}\text { Kemudahan staff untuk dihubungi guna } \\
\text { mendapat pelayanan sesuai masalah yang } \\
\text { dihadapi }\end{array}$ & 3.82 & 4.28 & 4.40 \\
\hline 18 & Tersedianya diskon atau promo menarik & 3.81 & 4.18 & 4.49 \\
\hline 19 & $\begin{array}{l}\text { Resepsionis memberi arahan sesuai dengan } \\
\text { kebutuhan calon pembeli dan pelanggan }\end{array}$ & 3.48 & 4.14 & 4.53 \\
\hline 20 & $\begin{array}{l}\text { Pelayanan terhadap calon pembeli dan } \\
\text { pelanggan tidak dilihat dari status sosial } \\
\text { (adil) }\end{array}$ & 3.84 & 4.23 & 4.38 \\
\hline
\end{tabular}

\section{Gap Servqual}

Nilai Gap atau nilai kesenjangan ini didapatkan dengan membandingkan atau menguranggi nilai rata-rata persepsi dengan nilai rata-rata harapan. Nilai gap ini dituliskan dalam rumus :

$\mathrm{Q}=\mathrm{P}-\mathrm{E}$

Penelitian ini menggunakan 95 responden dan telah melalui uji kecukupan minimal sampel. Hasil kuesioner kemudian dihitung nilai Gap dari dimensi yang ada pada metode Servqual. Nilai Gap atau kesenjangan ini diperoleh dengan membandingkan atau mengurangi nilai rata-rata persepsi dengan nilai rata-rata harapan. Berikut tabel hasil nilai Gap Servqual:

Tabel 10.

Gap Servqual

\begin{tabular}{|c|c|c|c|c|c|}
\hline Dimensi & No & Atribut Layanan & Persepsi & Harapan & Gap \\
\hline \multirow{4}{*}{$\begin{array}{l}\text { Tangible } \\
\text { (Berwujud) }\end{array}$} & 1 & Tempat ibadah yang bersih, rapi, dan nyaman & 3.87 & 4.18 & -0.31 \\
\hline & 2 & $\begin{array}{l}\text { Kelayakan fasilitas ruang tunggu (Televisi, AC, } \\
\text { Kipas angin, tempat duduk, dll) }\end{array}$ & 3.62 & 4.03 & -0.41 \\
\hline & 3 & Kelayakan Toilet & 3.68 & 3.97 & -0.29 \\
\hline & 4 & Kelayakan area parkir & 3.00 & 3.93 & -0.93 \\
\hline \multirow{4}{*}{$\begin{array}{l}\text { Reliability } \\
\text { (Keandalan) }\end{array}$} & 5 & Tempat ibadah yang bersih, rapi, dan nyaman & 3.12 & 3.92 & -0.80 \\
\hline & 6 & $\begin{array}{l}\text { Kelayakan fasilitas ruang tunggu (Televisi, AC, } \\
\text { Kipas angin, tempat duduk, dll) }\end{array}$ & 3.62 & 4.13 & -0.51 \\
\hline & 7 & Kelayakan toilet & 3.88 & 4.36 & -0.48 \\
\hline & 8 & Kelayakan area parkir & 3.08 & 4.00 & -0.92 \\
\hline
\end{tabular}


Rizky Stighfarrinata, Faisal Ashari

Integrasi Servqual, Kano dan QFD untuk Analisis peningkatan kualitas layanan

demi tercapainya kepuasan pelanggan PT. Kharisma Sejahtera Daihatsu

Cabang Bojonegoro

Jurnal MANOVA Volume V Nomor 1, ISSN : 2685-4716, E ISSN : 2746-282X

Tabel 10.

Gap Servqual (lanjutan)

\begin{tabular}{|c|c|c|c|c|c|}
\hline Dimensi & No & Atribut Layanan & Persepsi & Harapan & Gap \\
\hline \multirow{4}{*}{$\begin{array}{l}\text { Responsiveness } \\
\text { (Keandalan) }\end{array}$} & 9 & $\begin{array}{l}\text { Ketanggapan pihak perusahaan merespon dan } \\
\text { menanggapi keluhan calon pembeli dan } \\
\text { pelanggan }\end{array}$ & 3.72 & 4.26 & -0.54 \\
\hline & 10 & $\begin{array}{l}\text { Kecepatan petugas administrasi } \text { dalam } \\
\text { menyampaikan informasi terbaru kepada } \\
\text { petugas servis dan staff yang bertanggung } \\
\text { jawab }\end{array}$ & 3.36 & 3.95 & -0.59 \\
\hline & 11 & $\begin{array}{l}\text { Petugas resepsionis dan sales melayani calon } \\
\text { pembeli dan pelanggan dengan baik }\end{array}$ & 3.52 & 4.04 & -0.52 \\
\hline & 12 & Pimpinan dan staff standby selama jam kerja & 3.94 & 4.23 & -0.29 \\
\hline \multirow{4}{*}{$\begin{array}{r}\text { Assurance } \\
\text { (Jaminan) }\end{array}$} & 13 & $\begin{array}{l}\text { Suasana servis dan penjualan yang kondusif } \\
\text { dan menyenangkan }\end{array}$ & 3.45 & 4.15 & -0.70 \\
\hline & 14 & $\begin{array}{l}\text { Staff dan karyawan melayani calon pembeli dan } \\
\text { pelanggan dengan ramah dan sopan }\end{array}$ & 3.28 & 3.96 & -0.68 \\
\hline & 15 & Lingkungan perusahaan yang aman dan nyaman & 3.78 & 4.16 & -0.38 \\
\hline & 16 & $\begin{array}{l}\text { Konsultasi dalam rencana pembelian dan servis } \\
\text { kendaraan }\end{array}$ & 3.83 & 4.22 & -0.39 \\
\hline \multirow{4}{*}{$\begin{array}{l}\text { Emphaty } \\
\text { (Perhatian) }\end{array}$} & 17 & $\begin{array}{l}\text { Kemudahan staff untuk dihubungi } \\
\text { mendapat pelayanan sesuai masalah } \\
\text { dihadapi }\end{array}$ & 3.82 & 4.28 & -0.46 \\
\hline & 18 & Tersedianya diskon atau promo menarik & 3.81 & 4.18 & -0.37 \\
\hline & 19 & $\begin{array}{l}\text { Resepsionis memberi arahan sesuai dengan } \\
\text { kebutuhan calon pembeli dan pelanggan }\end{array}$ & 3.48 & 4.14 & -0.66 \\
\hline & 20 & $\begin{array}{l}\text { Pelayanan terhadap calon pembeli dan } \\
\text { pelanggan tidak dilihat dari status sosial (adil) }\end{array}$ & 3.84 & 4.23 & -0.39 \\
\hline
\end{tabular}

Berdasarkan Tabel 10 bisa dilihat bahwa semua atribut bernilai negatif yang menunjukkan bahwa kualitas layanan yang diberikan oleh PT. Kharisma Sejahtera Daihatsu Bojonegoro belum mampu memenuhi harapan calon pembeli dan pelanggan.

\section{Klasifikasi Kano}

Dalam penelitian yang dilakukan (Rahmana et al., 2014) diterangkan bahwa atribut pada setiap responden, yaitu dengan menggabungkan kedua jawaban atau pernyataan kuesioner fungsional dan disfungsional yang kemudian diklasifikasikan dengan menggunakan evaluasi model Kano menjadi enam kategori. Hasil kategori Kano yang dilakukan penelitian ini dijelaskan dalam Tabel 11 sebagai berikut: 

demi tercapainya kepuasan pelanggan PT. Kharisma Sejahtera Daihatsu

Tabel 11.

Kategori Model Kano

\begin{tabular}{|c|c|c|c|c|c|c|c|c|c|}
\hline \multirow{2}{*}{ No. } & \multirow{2}{*}{ Atribut } & \multicolumn{5}{|c|}{ Jumlah Jawaban } & & \multirow{2}{*}{ Total } & \multirow[t]{2}{*}{ Kategori } \\
\hline & & $\mathrm{M}$ & $\mathrm{O}$ & A & I & $\mathrm{R}$ & Q & & \\
\hline 1 & Atribut 1 & 10 & 73 & 8 & 4 & 0 & 0 & 95 & One-dimensional \\
\hline 2 & Atribut 2 & 20 & 41 & 19 & 15 & 0 & 0 & 95 & One-dimensional \\
\hline 3 & Atribut 3 & 34 & 27 & 11 & 23 & 0 & 0 & 95 & Must be \\
\hline 4 & Atribut 4 & 6 & 18 & 24 & 47 & 0 & 0 & 95 & Indifferent \\
\hline 5 & Atribut 5 & 24 & 37 & 5 & 29 & 0 & 0 & 95 & One-dimensional \\
\hline 6 & Atribut 6 & 21 & 46 & 17 & 11 & 0 & 0 & 95 & One-dimensional \\
\hline 7 & Atribut 7 & 7 & 75 & 10 & 3 & 0 & 0 & 95 & One-dimensional \\
\hline 8 & Atribut 8 & 17 & 39 & 9 & 30 & 0 & 0 & 95 & One-dimensional \\
\hline 9 & Atribut 9 & 13 & 63 & 15 & 4 & 0 & 0 & 95 & One-dimensional \\
\hline 10 & Atribut 10 & 46 & 27 & 13 & 9 & 0 & 0 & 95 & Must be \\
\hline 11 & Atribut 11 & 16 & 67 & 5 & 7 & 0 & 0 & 95 & One-dimensional \\
\hline 12 & Atribut 12 & 10 & 67 & 13 & 5 & 0 & 0 & 95 & One-dimensional \\
\hline 13 & Atribut 13 & 38 & 26 & 25 & 6 & 0 & 0 & 95 & Must be \\
\hline 14 & Atribut 14 & 37 & 26 & 11 & 21 & 0 & 0 & 95 & Must be \\
\hline 15 & Atribut 15 & 8 & 64 & 16 & 7 & 0 & 0 & 95 & One-dimensional \\
\hline 16 & Atribut 16 & 15 & 71 & 5 & 4 & 0 & 0 & 95 & One-dimensional \\
\hline 17 & Atribut 17 & 7 & 82 & 4 & 2 & 0 & $\underline{0}$ & 95 & One-dimensional \\
\hline 18 & Atribut 18 & 13 & 72 & 9 & 1 & 0 & 0 & 95 & One-dimensional \\
\hline 19 & Atribut 19 & 8 & 66 & 13 & 8 & 0 & 0 & 95 & One-dimensional \\
\hline 20 & Atribut 20 & 4 & 16 & 62 & 13 & 0 & 0 & 95 & Attractive \\
\hline
\end{tabular}

\section{Integrasi Servqual, Kano ke dalam Quality Function Deployment (QFD)}

Quality Function Deployment (QFD) merupakan metode perencanaan dan pengembangan produk yang memiliki tujuan untuk menerjemahkan kebutuhan pelanggan (Ocampo dkk, 2020) dan memenuhi kebutuhan pelanggan sesuai dengan sumber daya dan kemampuan yang dimiliki saat ini (Yazdani dkk, 2019). QFD biasa dilakukan dengan membuat matrikss korelasi antara kebutuhan dari pelanggan dan desain jasa atau produk berupa House Of Quality (HOQ) (Chen dkk, 2018). Dalam menyusun matriks House Of Quality (HOQ), yang terdiri atas matriks customer requirements atau voice of customer, planning matrix, technical requirements, relationship matrix, correlation matrix, score of the technical requirements atau prioritas kepentingan. Untuk bentuk matriks House Of Quality dapat dilihat pada gambar 6 berikut ini: 

demi tercapainya kepuasan pelanggan PT. Kharisma Sejahtera Daihatsu Cabang Bojonegoro

Jurnal MANOVA Volume V Nomor 1, ISSN : 2685-4716, E ISSN : 2746-282X

\section{2}

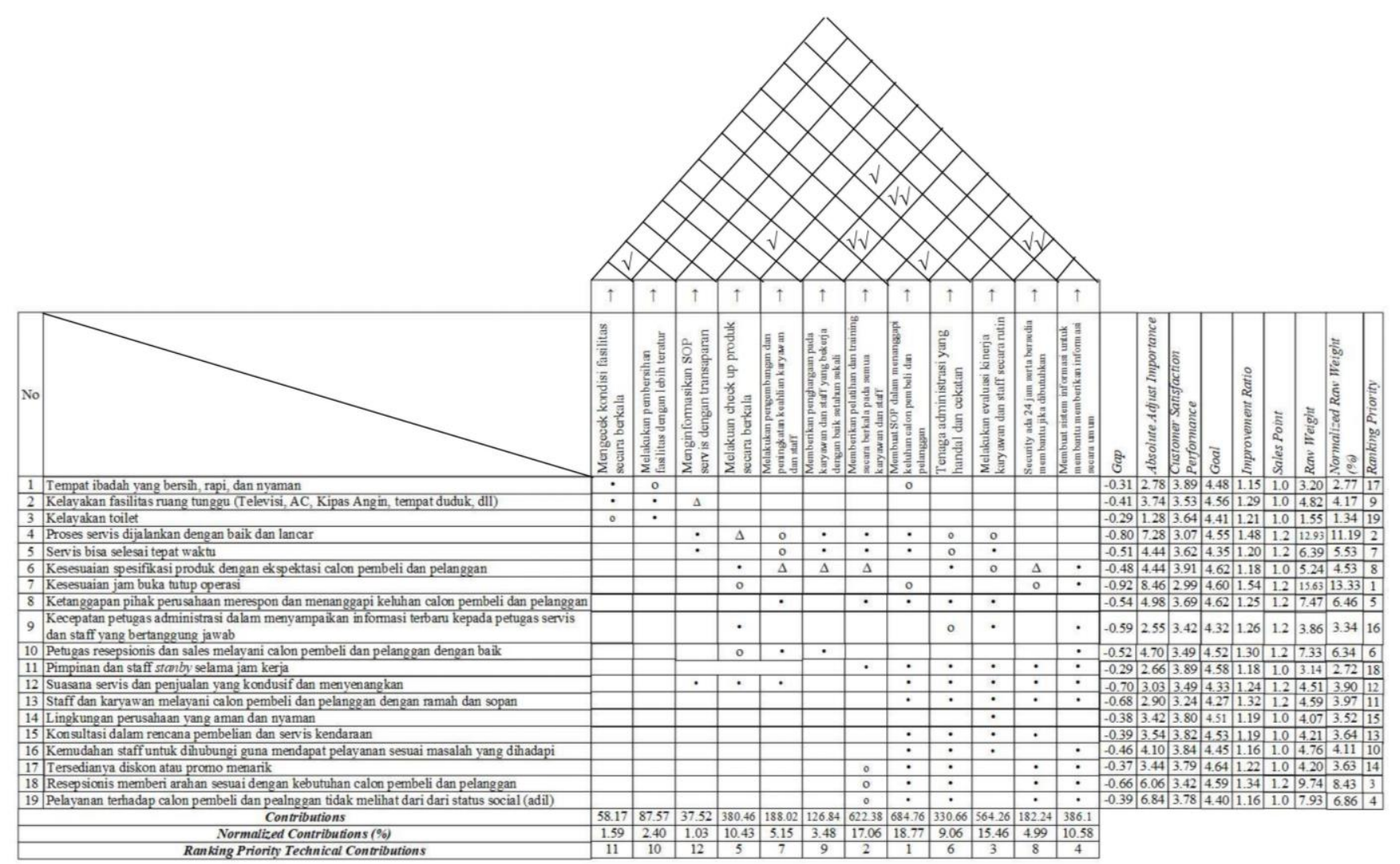

Gambar 6. HOUSE OF QUALITY 


\section{KESIMPULAN}

Dari pembahasan dilakukan analisa hasil penelitian dan diperoleh kesimpulan yaitu menggunakan metode Service Quality (Servqual) dapat disimpulkan bahwa semua atribut memiliki nilai gap negatif yang menunjukkan bahwa kualitas layanan yang diberikan oleh pihak PT. Kharisma Sejahtera Daihatsu Bojoengoro belum mampu memenuhi harapan calon pembeli dan pelanggan, hasil klasifikasi atribut layanan dengan menggunakan metode Kano, diperoleh 20 atribut layanan yang masuk ke dalam kategori penting, antara lain 4 atribut masuk kategori must-be, 14 atribut masuk kategori onedimensional, 1 atribut masuk kategori attractive, dan 1 atribut indifferent. Untuk kategori indeffrent dapat dihilangkan karena kategori tersebut tidak memberikan pengaruh pada tingkat kepuasan calon pembeli dan pelanggan, ketiga, hasil output metode QFD dengan memperhatikan nilai normalized raw weight (\%), diperoleh 5 urutan terbesar atribut yang diprioritaskan oleh pihak PT. Kharisma Sejahtera Daihatsu Bojonegoro. Atribut tersebut antara lain kesesuaian jam buka tutup operasi dengan nilai $13.53 \%$, proses servis dijalankan dengan baik dan lancar dengan nilai $11.19 \%$, resepsionis memberi arahan sesuai dengan kebutuhan calon pembeli dan pelanggan dengan nilai $8.43 \%$, pelayanan terhadap calon pembeli dan pelanggan tidak dilihat dari status sosial (adil) dengan nilai 6.86\%, dan ketanggapan pihak perusahaan merespon dan menanggapi keluhan calon pembeli dan pelanggan dengan nilai $6.46 \%$. Adapun upaya perbaikan yang perlu diutamakan oleh pihak PT. Kharisma Sejahtera Daihatsu Bojonegoro dalam meningkatan kualitas layanan untuk memuaskan calon pembeli dan pelanggannya berdasarkan 5 kontribusi tertinggi technical requirements adalah membuat SOP dalam menanggapi keluhan calon pembeli dan pelanggan dengan nilai kontribusi $18.77 \%$, memberikan pelatihan dan training secara berkala pada semua karyawan dan staff dengan nilai kontribusi $17.06 \%$, melakukan evaluasi kinerja karyawan dan staff secara rutin dengan nilai kontribusi $15,46 \%$, membuat sistem informasi untuk membantu memberikan informasi secara umum dengan nilai kontribusi $10.58 \%$, dan melakukan check up produk secara berkala dengan nilai kontribusi $10.43 \%$. 


\section{DAFTAR PUSTAKA}

Aji, I., Industri, M. T., Industri, F. T., Arief, J., \& Hakim, R. (2021). Integrasi Metode Servqual, KANO, dan QFD untuk Meningkatkan Kualitas Layanan ( Studi Kasus : Fakultas Teknik UG ). 1(4), 8-16.

Nurfadli, A., Studi, P., Teknik, M., \& Industri, F. T. (2020). Analisis Peningkatan Kualitas Layanan Pendidikan kepada Siswa menggunakan Metode CSI dan SERVQUAL. Seminar Nasional Sains Dan Teknologi Terapan VIII 2020 Institut Teknologi Adhi Tama Surabaya, 300-306.

Rahmana, A., Kamil, M., Soemantri, E., \& Olim, A. (2014). Integration of SERVQUAL and KANO Model Into QFD To Improve Quality of SimulationBased Training on Project Management. International Journal of Basic and Applied Science, 2(3), 59-72.

Sutariah, F. (2017). Evaluasi Kepuasan Mahasiswa Terhadap Kualitas Pelayanan Pendidikan Lembaga Pendidikan Tinggi ABC di Cikarang. Formatif: Jurnal Ilmiah Pendidikan MIPA, 7(1). https://doi.org/10.30998/formatif.v7i1.1372

Utami, E. (2015). Pendekatan Model Kano Pada Quality Function Deployment Untuk Perbaikan Kualitas Kegiatan Belajar Mengajar. Jurnal Ilmiah Teknik Industri, 187-195.

Wibisono, D. (2018). METODE SERVQUAL DAN QFD Deny Wibisono Jl . Nangka No . 58 C Tanjung Barat, Jagakarsa, Jakarta Selatan. 10(1), 57-74.

Yusuf R, I., Umar D, D., \& SD, T. (2017). Model Perumusan Strategi Peningkatan Kualitas Pelayanan Untuk Mencapai Kepuasan Mahasiswa Pada Politeknik Stmi Jakarta. Jurnal Teknik Industri, 7(1), 12-20. https://doi.org/10.25105/jti.v7i1.2203 